\title{
Mating behaviour of Simulium erythrocephalum (De Geer, 1776) (Diptera: Simuliidae) in Zaragoza (Spain)
}

\author{
Javier Alfonso Garza-Hernández ${ }^{1}$, Antonio De la Mora-Covarrubias ${ }^{1}$ \& Ignacio Ruiz-Arrondo 2,3 \\ 1 Laboratorio de Biotecnología, Instituto de Ciencias Biomédicas, Universidad Autónoma de Ciudad Juárez. Anillo Envolvente y \\ Estocolmo s/n, Zona Pronaf. C.P. 32310, Cd. Juárez, Chihuahua, México. \\ 2 Center of Rickettsiosis and Arthropod-Borne Diseases, Hospital San Pedro-CIBIR, C/ Piqueras 98, 3a planta, 26006, Logroño \\ (La Rioja), Spain. \\ 3 Department of Animal Pathology, Faculty of Veterinary Sciences, Universidad de Zaragoza, C/ Miguel Servet 177, 5013, \\ Zaragoza, Spain.
}

\section{Correspondence}

I. Ruiz-Arrondo

E-mail: irarrondo@riojasalud.es

Received: 5 May 2018

Accepted: 5 October 2018

Published on-line: 3 December 2018

\section{Resumen}

Comportamiento de apareamiento de Simulium erythrocephalum (De Geer, 1776) (Diptera: Simuliidae) en Zaragoza (España)

Simulium erythrocephalum (De Geer, 1776) es una especie altamente antropofílica responsable de brotes de mosca negra en España. Así, se realizaron observaciones sobre el comportamiento de apareamiento de $S$. erythrocephalum en condiciones naturales en España, incluyendo la formación de enjambres, el reconocimiento, abordaje y la finalización de la cópula y el comportamiento post cópula. Los resultados obtenidos demostraron que la actividad de cópula tiene lugar durante la tarde. Observamos como el ser humano representa un marcador de orientación atractivo para los enjambres de machos, cuya formación está relacionada con el período de actividad de búsqueda de hospedador por parte de las hembras. Este estudio representa el primer estudio sobre el comportamiento de cópula de simúlidos en España, ampliando el conocimiento general sobre este comportamiento en las moscas negras.

Palabras clave: Simulium erythrocephalum, mosca negra, cópula, España.

\begin{abstract}
Simulium erythrocephalum (De Geer, 1776) is a highly anthropophilic species that is responsible for blackfly outbreaks in Spain. Thus, field observations of the mating behaviour, including swarm formation, recognition and chasing, copulation, termination of copulation and post-copulation behaviour of $S$. erythrocephalum were conducted in a natural habitat in Spain. The obtained results demonstrated that mating activity occurs during the evening hours. We observed the human host represents an attractive orientation marker of male swarms, whose formation is related to the hostseeking activity period of females. This study represents the first report about the mating behaviour of Simuliidae species in Spain, increasing the general knowledge about this behaviour of blackflies.
\end{abstract}

Key words: Simulium erythrocephalum, Blackflies, Copulation, Spain. 


\section{Introduction}

Blackflies are important biting pests and vectors of several pathogens of humans and other warmblooded animals (Crosskey 1990, Adler et al. 2004). Simulium erythrocephalum (De Geer, 1776), which is widely distributed in 36 countries in the Paleartic ecozone (Adler \& Croskey 2018), is a highly anthropophilic species and it is responsible for blackfly outbreaks in Spain (RuizArrondo et al. 2014). The high abundance of blackfly adults in different regions of Spain means an emergent public health problem in the country, which entails, among other consequences, the increase of number of medical consultations due to arthropod bites (Ruiz-Arrondo et al. 2017).

At present, little is known about the mating behaviour of blackflies in nature (Adler et al. 2004). Historically, the first description of copulation in blackflies was given by Friederichs (1921), who observed the mating of few Simulium sp. Latreille, 1802 individuals in captivity. Since then, more authors have described the mating behaviour of blackflies (Smart 1934, Davies \& Peterson 1956, Peterson 1959, Downes 1969, Wenk \& Raybould 1972, Crosskey 1990). In relation to S. erythrocephalum, Wenk (1965) observed 14 successful matings of a laboratory reared population. Later, the same author (Wenk 1987) gave the first description of the mating behaviour of $S$. erythrocephalum observed in a natural habitat of the Rhine Valley near Strasbourg (Germany). The objective of this study was conduct field observations of the mating behavior of $S$. erythrocephalum in a natural habitat in Spain.

\section{Material and methods}

During the development of our field study, we used the direct observation method in order to provide descriptions of each phase of the mating behaviour scenario (swarm formation, recognition and chasing, copulation (coitus) and termination of copulation, including post-copulation behaviour of males) of $S$. erythrocephalum in a natural habitat located in the province of Zaragoza, Spain. The field study was conducted in the district of $\mathrm{La}$ Cartuja (coordinates: 41 $36^{\circ} 55.97^{\prime \prime} \mathrm{N}, 00^{\circ} 49^{\prime} 52$. 57 "W, altitude: 185 MASL), close to the city of Zaragoza, Spain (Figs. 1 A, 1B), where productive breeding sites of $S$. erythrocephalum were recorded.

The observations were conducted by two col- lectors of blackflies (first and third authors, served as volunteers) while they were developing the human-landing-collection (HLC) method in order to study the daily pattern of human-landing activity of $S$. erythrocephalum. The collectors were sitting in the open field, at a distance of $109 \mathrm{~m}$ from the banks of the Ebro River and $75 \mathrm{~m}$ apart each other, under a natural shadow of Salix L. sp. and Populus L. sp. trees (Fig. 1 C, D). Along with the HLC study, the mating behaviour observations were conducted during the period of 12 consecutive days, from May 29th to June 9th, 2015, starting at 6:30 AM and ending at 20:30 PM (Central European Summer Time, UTC $+2 \mathrm{~h}$ ) each day (for more information see Ruiz-Arrondo et al. 2017). Males from swarms were captured using an aerial insect net while they were flying inside the male swarms. Pairs in copulation were collected by mouth aspirators. Specimens were maintained in gel-ice portable coolers, and transported to the laboratory. Morphological identification of the individuals collected was based on keys of Rivosecchi et al. (2007).

During the study, the hourly meteorological data related to air temperature $\left({ }^{\circ} \mathrm{C}\right)$, relative humidity (\%) and solar radiation $\left(\mathrm{W} / \mathrm{m}^{2}\right)$ were obtained from the nearest regional meteorological station in Pastriz (Zaragoza, Spain; 41 ${ }^{\circ} 35^{\prime}$ $39.40^{\prime \prime} \mathrm{N}, 00^{\circ} 43^{\prime} 49.48^{\prime \prime} \mathrm{W}, 192$ MASL. Besides, the illuminance (lux) was recorded using the App Light Lux Meter v.2.2 for tablet Samsung Galaxy Tab 2. GT-P5100ZWMTTT during the observation of the mating behaviour activity.

\section{Results and discussion}

In the present study, we observed only the formation of swarms by males. A total of 10 males from 3 different swarms and 3 pairs in copulation were caught. All individuals were identified as $S$. erythrocephalum. In Zaragoza, only $S$. erythrocephalum was captured using HLC method, despite other three species (Simulium sergenti [Edwards, 1923], Simulium lineatum [Meigen, 1804] and Simulium equinum [L., 1758]) shared the breeding sites with this anthrophilic species (Ruiz-Arrondo et al. 2017). The mating of S. erythrocephalum was observed during the last five days of the study period (June 5-9 $9^{\text {th }}, 2015$ ). Formation of male swarms was always observed as prerequisite for mating. The swarms were approaching the observer (i.e. HLC) exposed landing activity of blackflies. Human host acting as a 



Figura 1. Área de estudio y zona de captura. A: Ciudad de Zaragoza, España (flecha blanca); B: Barrio de La Cartuja en la ciudad de Zaragoza, con el punto de muestreo del estudio (círculo rojo y flecha blanca) y la estación meteorológica regional de Pastriz (círculo amarillo y flecha blanca); C: Tipo de vegetación cerca de las orilla del río Ebro; D: Posición del marcador humano cuando se realizaron las observaciones de cópula (flecha blanca).

Figure 1. Study area and collection site. A: Municipality of Zaragoza, Spain (white arrow); B: District of La Cartuja in the city of Zaragoza, with the sampling site for the study (red circle and white arrow) and the regional meteorological station in Pastriz (yellow circle and white arrow). C: Vegetation type near of the River Ebro's riverbanks. D: Position of the human marker where mating observations were conducted (white arrow).

marker for swarming has been previously described by Wenk (1987), such as S. equinum and $S$. erythrocephalum. Ignjatović-Ćupina (2011) observed $S$. erythrocephalum males flying around the head of the host (cows and humans) creating a swarm many times at the start of eclosion of a new generation.

Although this species showed a bimodal landing activity pattern, with a minor peak at dawn and a major peak at dusk in Zaragoza (Ruiz-Arrondo et al. 2017), we observed the formation of swarms during the evening hours, exclusively, between 18:00 and 21:00 PM (at mean temperature of $26.78 \pm 0.81^{\circ} \mathrm{C}$ and mean relative humidity of $37.40 \pm 2.81 \%$ ). This behaviour does not coincide with the description of Yuval (2006), who explained that mating activity of blackflies (in general) occurs primarily on full daylight. Also, Peterson (1959), noted that males of Simulium arcticum (Malloch, 1914) (complex of nearctic species) were swarming during the daylight at 14:30 over the headwaters of the Provo River in Utah, USA. According to Ruiz-Arrondo et al. (2017), the bimodal daily landing-activity pattern of $S$. erythrocephalum was affected by temperature and solar radiation.

The optimal temperature for host-seeking activity of $S$. erythrocephalum was between 22.17 to $27.35^{\circ} \mathrm{C}$ in the evening. With regard to solar radiation, blackflies showed host-seeking activity at values below $123.51 \mathrm{~W} / \mathrm{m}^{2}$ (evening hours) with the most intensive host-seeking behaviour at solar radiation of $8 \mathrm{~W} / \mathrm{m}^{2}$, recorded at 20:30 PM, in conditions of dim sunlight (Ruiz-Arrondo et al. 2017). In this context, in our study the first swarm was observed at the illuminance value of 300 lux and the last one at 45 lux. Later on, in absence of females in host-seeking behaviour (i.e. blood- 


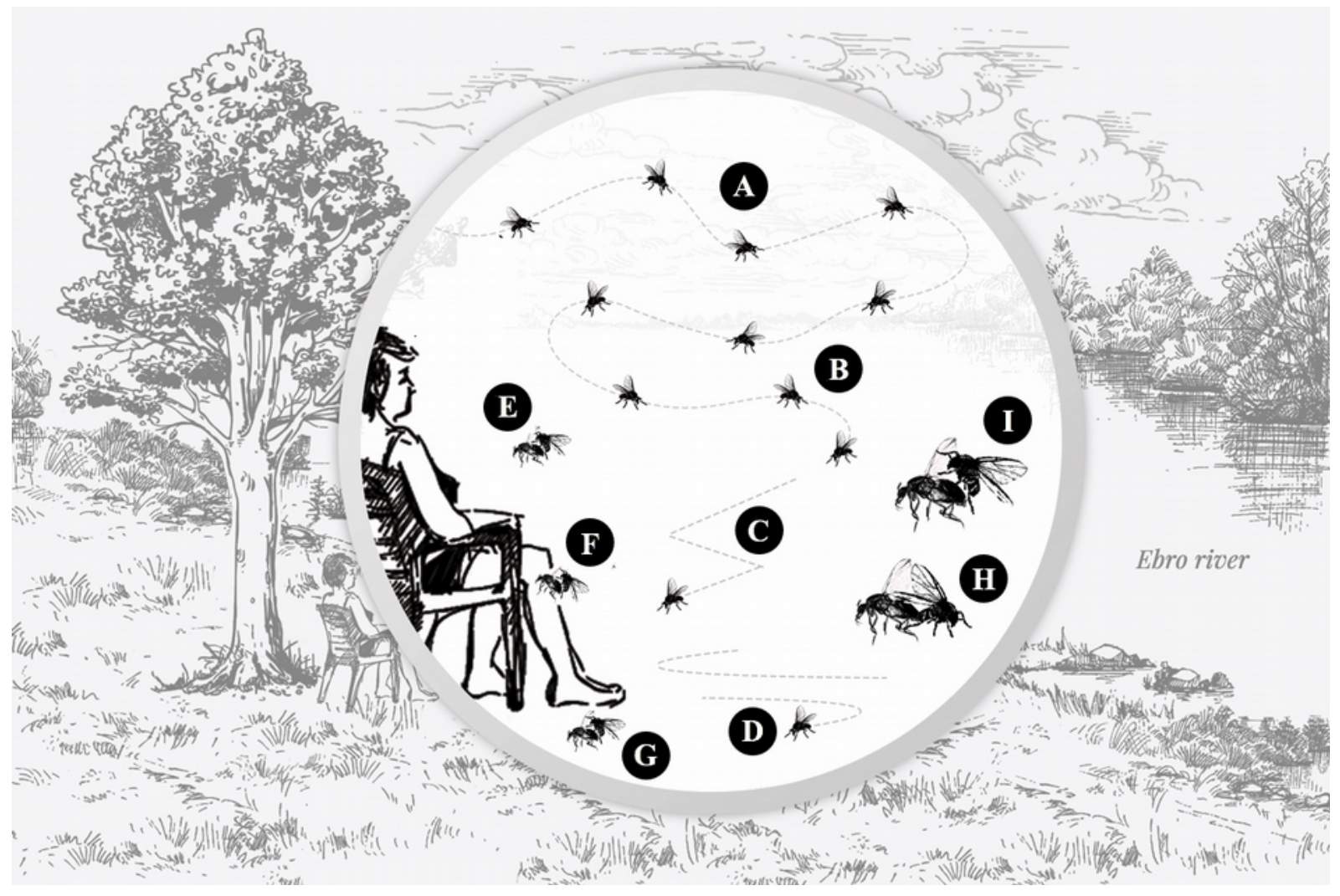

Figura 2. Esquema del enjambre y comportamiento de apareamiento de Simulium erythrocephalum. A: Formación del enjambre. B: Movimiento del enjambre; C: Vuelo del macho en zig-zag; D: Movimiento del macho en espiral; E: Contacto aéreo macho-hembra; F: Cópula sobre el hospedador humano; G: Cópula sobre el suelo; H: Posición de cópula end-to-end; I: Posición de cópula male-above-female. Autores: Javier A. Garza-Hernández, Ignacio Ruiz-Arrondo y Sergio Simón-Petreñas (Estudio Bogart \& Bacall).

Figure 2. Scheme of the swarming and mating behaviour of Simulium erythrocephalum. A: Formation of the swarm; B: Swarming movement; C: Zig-zag flying of male; D: Swirl flying of male; E: Aerial male-female contact; F: Copulation on the human host; G: Copulation on the ground; H: End-to-end copulation position; I: Male-above-female copulation position. Authoring: Javier A. GarzaHernández, Ignacio Ruiz-Arrondo and Sergio Simón-Petreñas (Bogart \& Bacall studio).

sucking activity) the swarms of males disappeared. Therefore, our observation results, related to $S$. erythrocephalum suggests that the mating period of blackfly species that use hosts as visual markers for swarming is primarily subordinated to the host-seeking activity period of females during the evening hours.

We observed simultaneously the formation of 2 or 3 swarms per host, each one composed of 10 to 15 males (Fig. 2A). The movement of the swarm was a unit with wavering movements as a swirl-flying (Fig. 2B), as about 2 to $3 \mathrm{~m}$ in front of the head of the human marker. Wenk (1987) reported the swarms of $S$. erythrocephalum males may consist of a few individuals to up to hundreds or even thousands on certain days. Wenk (1987) also explained that in male swarms exists a hierarchical order in the positions to the optic marker, since males keep a more or less constant distance from each other and compete for the best position within the swarm. As the observers were standing in the same position (for HLC procedure), we could not see if the swarms would follow the movement of the host.

With regard to recognition and chasing of a female by the males from a swarm, a single male detected a female and then the male flew out of the swarm in a swirling or zig-zag flying path (Figs. 2C, 2D) to chase the female. Immediately, the male captured one receptive female in-flight (Fig. 2E), and at that time both fell down on the ground (Fig. 2G) or on the human host (Fig. 2F) (we registered only one couple in act of copulation on the human host, while the female was taking the blood meal). These observations are similar to those made by Ignjatović-Ćupina (2011) who observed that $S$. erythrocephalum male flies tackled the females to falling down on the ground or on the host body (human or cow) for copulation. This phenomenon is not restricted to hematophagous dipterans and it has been observed also for phytophagous dipterans; i.e. in the 
mediterranean fruit fly Ceratitis capitate (Wiedemann, 1824) (Diptera: Tephritidae) copulation (coitus) occurred on the bottom surfaces of sunlit leaves (Whittier et al. 1992). Subsequently, the couple adopted end-to-end position (Fig. 2H), described by Crosskey (1990) and Adler et al. (2004) as a common copulation position in blackflies, and also present in mosquitoes, such as Aedes aegypti (L. 1762) (Jones \& Pilitt 1973). Nevertheless, we noted that couples also adopt the position male-above-female (Fig. 2I), described by Adler et al. (2004) as an initial position in copulation of blackflies. We succeeded to record the duration of copulation accomplishment three times, which ranged from 3 to 5 seconds (3.50, 4.50 and 5.00 seconds). Similarly, to our results, Crosskey (1990) noted that the copulation of S. erythrocephalum in laboratory conditions lasts from 1 to 5 seconds. Finally, we observed that after the termination of the copulation, males flew back in the direction of the swarm to join it again, suggesting that males of $S$. erythrocephalum may mate more than one time.

In conclusion, we point out that our study, represents the first report about the mating behaviour of a blackfly species in natural field conditions of Spain. Also, we increase the knowledge about the copulation behaviour of blackflies.

\section{Acknowledgments}

We appreciate the authorities of Zaragoza for providing the permission to conduct the fieldwork in the district of La Cartuja to accomplishment of the present study. Partial results from this study were presented at the VII International Simuliidae Symposium held in Zaragoza, Spain, in September 2016. We thank Dr. Ana Palomar for her review of the final version of the manuscript and Sergio Simón for his help with the Figure 2. Javier A. Garza-Hernández thank to institutional project (Reference No. CIP-ICB-2018-1-03) which permitted the completion of the present manuscript.

\section{References}

Adler P \& Crosskey RW. 2018. World blackflies (Diptera: Simuliidae): a comprehensive revision of the taxonomic and geographical inventory [2018]. Available at: https://biomia.sites.clemson.edu/pdfs/blackflyinventory.pdf.

Adler PH, Currie DC \& Wood DM. 2004. The black flies
(Simuliidae) of North America. New York: Cornell University Press.

Crosskey RW. 1990. The Natural History of Blackflies. New York: John Wiley and Sons.

Davies DM \& Peterson BV. 1956. Observations on the mating, feeding, ovarian development, and oviposition of adult black flies (Simuliidae, Diptera). Canadian Journal of Zoology 34: 615-655.

Downes JA. 1969. The swarming and mating flight of Diptera. Annual Review Entomology 14: 271-298.

Friederichs K. 1921. Untersuchungen über Simuliiden (Teil II). Bulletin of Entomological Research 8: 23-42.

Ignjatović-Ćupina A. 2011. Fauna simulida (Diptera: Simuliidae) pribrežja Fruške gore. (Black fly fauna (Diptera: Simuliidae) of the Fruška gora foothills). Univerzitet u Novom Sadu.

Jones JC \& Pilitt DR. 1973. Observations on the sexual behavior of free-flying Aedes aegypti mosquitoes. $\mathrm{Bi}$ ological Bulletin 144: 480-488.

Peterson BV. 1959. Observations on mating, feeding, and oviposition of some Utah species of black flies (Diptera: Simuliidae) 1. Canadian Entomology 91: 147-155.

Rivosecchi L, Addonisio M \& Maiolini B. I Ditteri Simulidi. 2007. Nuove chiavi dicotomiche per l' identificazione delle specie italiane con brevi note bio-tassonomiche. Trento: Quaderni del museo Tridentino di Scienze naturali, 2.

Ruiz-Arrondo I, Alarcón-Elbal PM, Figueras L, Delacour-Estrella S, Muñoz A, Kotter H, Pinal R \& Lucientes J. 2014. Expansión de los Simúlidos (Diptera: Simuliidae) en España: Un nuevo reto para la Salud Pública y la Sanidad Animal. Boletín de la Sociedad Entomológica Aragonesa. 54:193-200.

Ruiz-Arrondo I, Garza-Hernández JA, Reyes-Villanueva F, Lucientes-Curdi J \& Rodríguez-Pérez MA. 2017. Human-landing rate, gonotrophic cycle length, survivorship, and public health importance of Simulium erythrocephalum in Zaragoza, northeastern Spain. Parasites \& Vectors 10: 175-184

Smart J. 1934. Notes on the Biology of Simulium pictipes Hagen. Canadian Entomologist 66: 62-66.

Wenk P. 1965. Ueber die Biologie blutsaugender Simuliiden. Zeitschrift für Morphologie und Ökologie der Tiere 55: 671-713.

Wenk P. 1987. Swarming and mating behavior of black flies. In Black Flies Ecology, Population Management and Annotated World List (Kim KC \& Merrit W, eds.). Pennsylvania: Pennsylvania State University Press, pp. 215-227.

Wenk P \& Raybould JN. 1972. Mating, blood feeding, and oviposition of Simulium damnosum Theobald in the laboratory. Bulletin of World Health Organization 47: 626-627.

Whittier TS, Kaneshiro KY \& Prescott LD. 1992. Mating behavior of Mediterranean fruit flies (Diptera: Tephritidae) in a natural environment. Annals of the Entomological Society of America 85: 214-218.

Yuval B. 2006. Mating systems of blood-feeding flies. Annual Review Entomology 51: 413-440. 